\title{
A NUMERICAL MODELING STUDY ON UPWELLING MECHANISM IN SOUTHERN MAKASSAR STRAIT
}

\author{
Agus S. Atmadipoera ${ }^{1^{*}}$ and Priska Widyastuti ${ }^{1}$, \\ ${ }^{1}$ Department of Marine Science and Technology, Bogor Agricultural University, \\ Bogor; *E-mail: atmadipoera_itk@ipb.ac.id
}

\begin{abstract}
While it has been well documented in the previous studies that upwelling events in the southern Makassar Strait (MAK) during the Southeast Monsoon (SEM) period are associated with low sea surface temperature (SST) and high chlorophyll-a (Chl-a) concentrations in the seawater, the dynamic and physical processes that trigger these upwelling events are still less well understood. In the present study we proposed a mechanism of the upwelling event using a numerical model of the Regional Ocean Modeling System (ROMS). Model validations showed a high correlation of SST climatology between the model and the NOAA-AVHRR satellite data. Moreover, velocity fields of the Indonesian Throughflow (ITF) Makassar in Libani Channel was well reproduced by proposed model, revealing an intensification of the flow centered near 120 $m$ depth, which is in good agreement with the observation data. The model demonstrated that during the SEM period strong southeasterly winds that blow over southern Sulawesi Island can increase high vertical diffusivity and heat loss through heat flux. Hence, these physical processes lead to increased vertical mixing that, in turn, generates low SST, as a proxy of upwelling event. Furthermore, the upwelling process is enhanced by the ITF Makassar jet that creates large circular eddies flow due to complex topographic within the triangle area of southern Makassar - eastern Java Sea - western Flores Sea. The eddies generate the area of convergence offshore along the ITF pathways and divergence area in the coastal waters close to southern Sulawesi Island. Model experiment with closing/opening Selayar Strait revealed a change of intensity and area of upwelling, suggesting that the Selayar Island forms a barrier for the outflow from MAK to northern part of Flores Sea.
\end{abstract}

Keywords: Upwelling, ITF Makassar, SE monsoon winds, ROMS-AGRIF, Makassar Strait.

\begin{abstract}
ABSTRAK
Upwelling di bagian selatan Selat Makassar (MAK) dicirikan oleh rona khas permukaan laut dari data satelit, seperti rendahnya suhu permukaan laut (SPL) dan tingginya klorofil-a yang terjadi dalam periode monsoon tenggara (SEM). Kajian proses interaksi laut-atmosfer dan dinamika laut yang memicu terjadinya upwelling di wilayah ini masih belum banyak diteliti. Tujuan dari makalah ini untuk mengkaji mekanisme upwelling dengan menggunakan pemodelan laut ROMS-AGRIF. Hasil model menunjukkan bahwa gaya pembangkit utama upwelling adalah dorongan angin kuat monsoon tenggara yang menghasilkan transport Ekman kearah baratdaya di kawasan selatan Pulau Sulawesi. Gesekan angin permukaan ini dapat meningkatkan difusivitas vertikal dan pelepasan fluks bahang ke atmosfer. Sehingga proses tersebut meningkatkan aktivitas percampuran massa air secara vertikal, yang berimplikasi terhadap menurunnya SPL. Proses upwelling ini juga diperkuat oleh adanya resirkulasi dari jet Arus Lintas Indonesia (ARLINDO) Makassar yang membentuk pusaran arus besar (eddies), yang terjadi karena konfigurasi topografi yang kompleks di sekitar wilayah studi. Pusaran arus tersebut berimplikasi terhadap terbentuknya wilayah konvergensi di laut lepas pada lintasan ARLINDO serta wilayah divergensi di perairan dekat pantai di selatan Pulau Sulawesi. Selain itu, hasil simulasi dengan eksperimen on/off Selat Selayar, menunjukkan bahwa konfigurasi Kepulauan Selayar dapat mempengaruhi intensitas dan luasan upwelling di wilayah studi.
\end{abstract}

Kata kunci: Upwelling, ARLINDO Makassar, Angin Monsun Tenggara, ROMS-AGRIF, Selat Makassar. 


\section{INTRODUCTION}

Southern Makassar Strait (MAK), which located in Southern Sulawesi area (2-8 ${ }^{\circ} \mathrm{S}$ and $\left.116-122^{\circ} \mathrm{E}\right)$, is well-known for having a high abundance of marine and fisheries source in the field of fisheries. This area includes the Makassar Strait, Java Sea and Flores Sea. In May, MAK is covered by warm sea surface temperature (SST) of about $29-30{ }^{\circ} \mathrm{C}$ and the concentration of Chlorophyll-a (Chl-a) is typically low $\left(\sim 0.3 \mathrm{mg} \mathrm{m}^{-3}\right)$. In August, however, the Chl-a concentration increases to a maximum of $1.3 \mathrm{mg} \mathrm{m}^{-3}$ (Setiawan et al., 2010). From December to March the surface waterin this area usually has the highest temperature and the lowest salinity, whereas in the period from June to November the temperature is low and the salinity is high (Susanto et al., 2012). High-salinity surface Makassar water is advected into Java Sea during the Southeast Monsoon (SEM) period (Atmadipoera et al., 2009).

The MAK is also influenced by Indonesian Throughflow (ITF) jet which is passing the Makassar Strait as the primary inflow path of ITF within the interior Indonesian seas. The mean transport volume in the Makassar Strait from January 2004 through November 2006 was $11.6 \pm 3.3 \mathrm{~Sv}\left(\mathrm{~Sv}=10^{6} \mathrm{~m}^{3} \mathrm{~s}^{-1}\right)$ and reached its maximum towards the end of the northwest and southeast monsoons (April-June), with minimum transport was from October to December (Gordon et al., 2008). During the SEM, the surface southeasterly winds blow steadily with the gradual increase of the wind speeds from May to August and the winds are quasiparallel to the coastline of Southern Sulawesi Island (Habibi et al., 2010). This situation leads to the upwelling event, which is followed by high abundance of fish and other marine biota in this area (Setiawan et al., 2010; Habibi et al., 2010). The upwelling event is highly associated with a large standard deviation of SST and Chl-a concentrations (Syahdan et al., 2014ab) (Figure 1). The analysis of upwelling indication from satellite imagery had previously been investigated (Setiawan et al., 2010; Habibi et al., 2010), however, its dominant forcing and mechanism are not well understood yet. A better knowledge of the upwelling mechanisms in this area is essential. Among the methods to describe the mechanism are by numerical model approaches such as Regional Ocean Modeling System (ROMS) and its nesting enabled version (Adaptative Grid Refinement in FortranAGRIF). These models are a free surface terrain following primitive equation hydrostatic model, configurable for realistic regional applications (Marta-Almeida et al., 2010).

ROMS-AGRIF has been applied to investigate numerous ocean phenomena, e.g., the meso-scale eddy-induced reduction in eastern boundary upwelling systems (Gruber et al., 2011), the upwel-ling limitation by geostrophic onshore flow (Marchesiello et al., 2011), the simulation of phytoplankton ecosystem dynamics in the California Current System (Gruber et al., 2006), a study of chlorophyll bloom in the western Pacific at the end of the 19971998 El Nino (Messie et al., 2006), and a high-resolution modeling of the sediment erosion and the particle transport across the northwest African shelf (Karakas et al., 2006).

A few research about the upwelling phenomenon in this region have been conducted. Besides, the complexity of the topography which induces an eddy-type throughflow from Kartadikaria et al. (2012), eddy-resolving model results proposed the hypotheses regarding the interaction to the upwelling process. This present study describes the dynamics and physical processes of the upwelling mechanism based on the following hypotheses: 1) coastal divergence around 

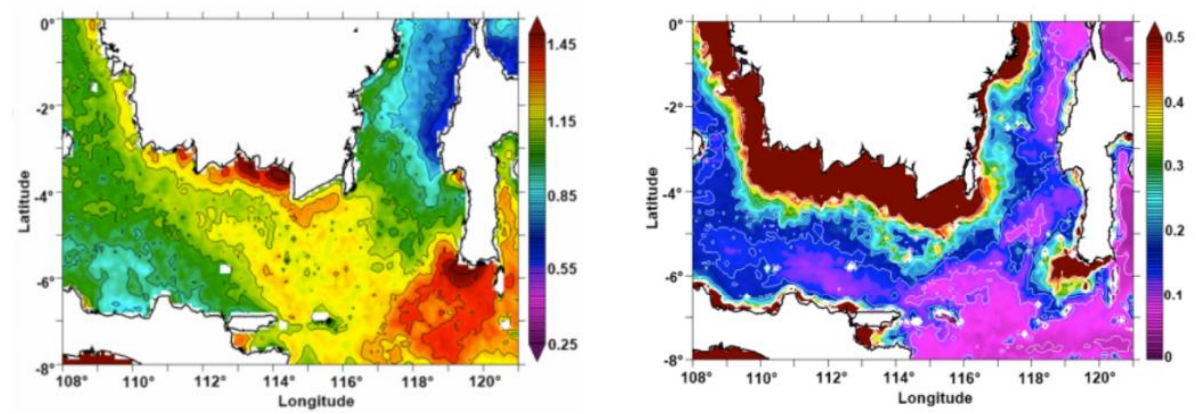

Figure 1. Standar deviation of sea surface temperature [unit in ${ }^{\circ} \mathrm{C}$ ] (left) and surface chlophyll-a concentration [unit in $\mathrm{mg} / \mathrm{l}$ ] (right), showing high standard deviation of parameters in southern tip of Sulawesi Island (after Syahdan et al. 2014ab)

MAK; 2) recirculation of surface ITF affected by the SEM winds; 3) water exchange across Selayar Strait; or 4) the combination of the three hypotheses is causing the upwelling in the MAK area. In addition, we attempted to describe the impact of the interaction between topography and sea currents on the upwelling intensity, distribution of upwelling and the annual cycle of atmospheric and oceanic parameters in MAK.

\section{METHODS}

\subsection{Data}

Inputs of the model were obtained from the World Databases and Research Center (Penven et al., 2007). Surface forcings (heat flux, air-sea parameter, freshwater flux) were obtained from COADS05 (Comprehensive Ocean Atmosphere Data Set), bathymetry was obtained from ETOPO-01, high resolutions $(9.28 \mathrm{~km})$ monthly global SST was obtained from AVHRR (Advanced Very High Resolution Radiometer) - Pathfinder Observations 1985-1997, wind stress monthly climatology was obtained from QuickSCAT, sea water properties was obtained from World Ocean Database (2006) and lateral boundary conditions were obtained from Drakkar INDO-
ORCA05 climatology simulations (19702003).

The model domain covers the upwelling area in MAK between 2-8 ${ }^{\circ} \mathrm{S}$ and $116-122^{\circ} \mathrm{E}$. The bottom topography in MAK is complex, with a narrow channel directing towards the southeast and a Dewakang sill ( $~ 860 \mathrm{~m}$ depth) just west of Selayar Island (Figure 2). Selayar Strait is located between southern tips of Makassar and Selayar Island, which may convey the water exchange between MAK and Flores Sea.

\subsection{Model Configuration}

The model configuration was performed by ROMS-AGRIF. ROMS resolves the primitive equations (Boussinesq approximation and hydrostatic vertical momentum balance). ROMS is a free surface oceanic model (short time steps are used to advance the surface elevation and barotropic momentum equations (larger time steps) are used for temperature, salinity, and baroclinic momentum) with robust open boundaries, grid refinement, sediment, and ecosystem modules. ROMS simulation needs horizontal grid data (grid position, grid size), topography, land mask, surface forcing (wind stress, surface heat flux, and freshwater flux), initial conditions (temperature, salinity, 


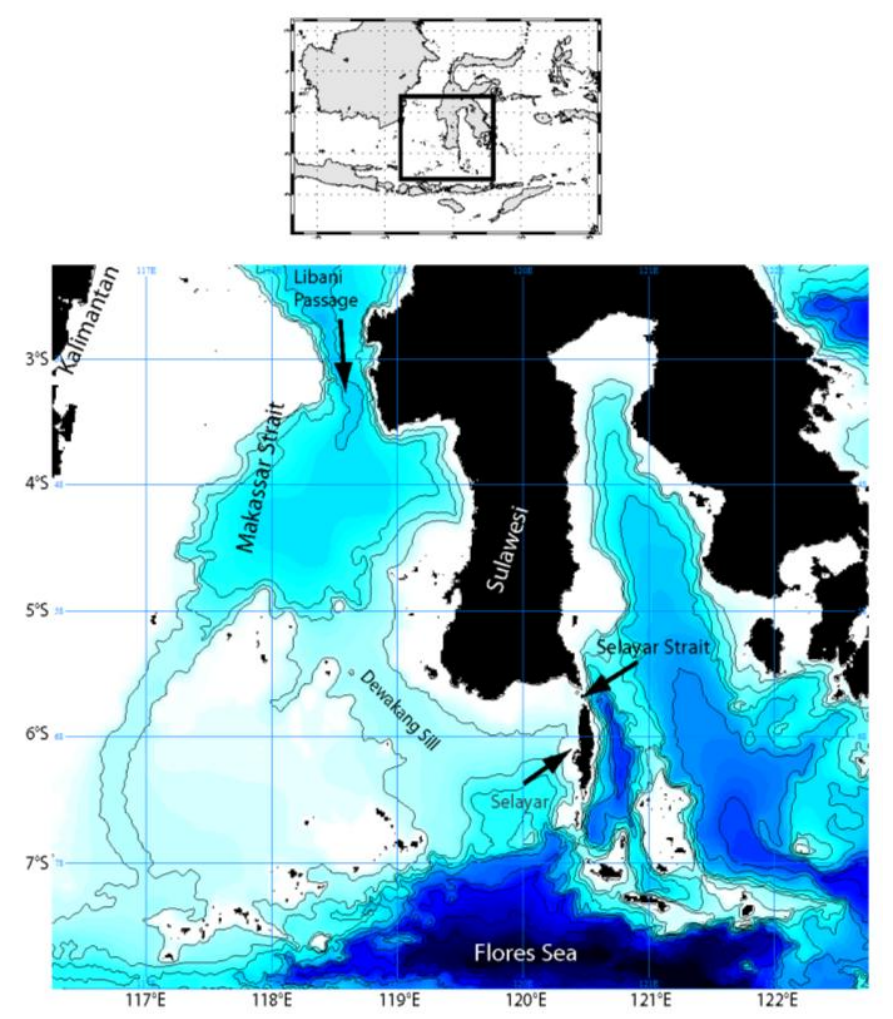

Figure 2. Model domain in southern Makassar Strait and part of western Flores Sea and eastern Java Sea. Interval of isodepth contours is every $500 \mathrm{~m}$. Libani Channel is deep narrow passage near 119E, 3S.

currents, sea surface height) and lateral boundary conditions.

In the primitive equations in Cartesian coordinates, the momentum balance in the $\mathrm{x}$ - and $\mathrm{y}$-directions are:

$$
\begin{aligned}
& \frac{\partial u}{\partial t}+\vec{u} \cdot \nabla u-f v=-\frac{1}{\rho 0} \frac{\partial P}{\partial x} \\
&+ \nabla_{h}\left(K_{M h} \cdot \nabla_{h} u\right)+\frac{\partial}{\partial z}\left(K_{M v} \frac{\partial u}{\partial z}\right)(1) \\
& \frac{\partial v}{\partial t}+\vec{u} \cdot \nabla v-f u=-\frac{1}{\rho 0} \frac{\partial P}{\partial y}+ \\
& \nabla_{h}\left(K_{M h} \cdot \nabla_{h} v\right)+\frac{\partial}{\partial z}\left(K_{M v} \frac{\partial v}{\partial z}\right)
\end{aligned}
$$

$u$ and $v$ are 2 -D velocity fields; $\vec{u} . \nabla u$ and $\vec{u} . \nabla v$ are advection terms; $f$ is Coriolis parameter; $\rho 0$ is water density; $P$ is total pressure; $h$ is mixed layer depth; $K_{M h}$ is horizontal mixing coefficient; and $K_{M v}$ is vertical mixing coefficient. The hydrostatic primitive equations for momentum are solved using a splitexplicit time-stepping scheme which requires special treatment and coupling between barotropic (fast) and baroclinic (slow) modes. In the vertical, the primitive equations are discretized over variable topography using stretched terrainfollowing coordinates. In the horizontal, the primitive equations are evaluated using boundary-fitted, orthogonal curvilinear coordinates on a staggered Arakawa C-grid. The equation of state is given by:

$$
\rho=\rho(S, T, P)
$$

$S$ is salinity and $T$ represents temperature. In the Boussinesq approximation, density variations are neglected in the vertical momentum equations except in their contribution to the buoyancy force in the vertical momentum equation. Under the hydrostatic approximation, it is further assumed that the vertical pressure gradient balances the buoyancy force: 


$$
0=-\frac{\partial P}{\partial z}-\partial g
$$

$P$ is total pressure; and $g$ is acceleration of gravity. The final equation expresses the continuity equation for an incompressible fluid:

$$
0=\frac{\partial u}{\partial x}+\frac{\partial v}{\partial y}+\frac{\partial w}{\partial z}
$$

The diagnostics analysis was computed online used tracer equation terms:

$$
\begin{gathered}
\frac{\partial T}{\partial t}+\vec{u} . \nabla T=\nabla_{h}\left(K_{T h} \cdot \nabla_{h} T\right)+ \\
\frac{\partial}{\partial z}\left(K_{T v} \frac{\partial T}{\partial z}\right) \\
\frac{\partial S}{\partial t}+\vec{u} . \nabla S=\nabla_{h}\left(K_{S h} \cdot \nabla_{h} S\right)+ \\
\frac{\partial}{\partial z}\left(K_{S v} \frac{\partial S}{\partial z}\right)
\end{gathered}
$$

$\vec{u} . \nabla T$ and $\vec{u} . \nabla S$ are advection terms ; $K_{T h}$ is horizontal mixing coefficient for temperature; and $K_{T v}$ is vertical mixing coefficient for temperature.

Analysis on boundary conditions are divided into two parts, with surface boundary conditions $(\mathrm{z}=\eta)$ and with bottom boundary conditions $(\mathrm{z}=-\mathrm{H})$. The equations for surface boundary conditions are:

$$
\begin{gathered}
\frac{\partial \eta}{\partial t}=w \\
K_{M v} \frac{\partial u}{\partial z}=\frac{\tau_{x}}{\rho 0} \\
K_{M v} \frac{\partial v}{\partial z}=\frac{\tau_{y}}{\rho 0} \\
K_{T v} \frac{\partial T}{\partial z}=\frac{Q}{\rho 0 C_{p}} \\
K_{S v} \frac{\partial S}{\partial z}=\frac{S(E-P)}{\rho 0}
\end{gathered}
$$

where $\tau_{x}$ and $\tau_{y}$ are wind stress at $\mathrm{x}$ and $\mathrm{y}$ directions; $u, v, w$ are 3-D velocity fields; $\rho_{0}$ is sea water density $\left(\rho=1025 \mathrm{~kg} \mathrm{~m}^{-3}\right.$ and $\left.C_{p}=4.1855 \times 10^{3} \mathrm{PSI}\right) ; \mathrm{T}$ is mixed layer depth temperature; and $K_{v}$ is vertical diffusivity coefficient (estimated by ROMS KPP scheme). The equations for bottom boundary conditions are:

$$
\begin{gathered}
\vec{u} \cdot \nabla(-H)=w \\
K_{M v} \frac{\partial u}{\partial z}=\frac{-C_{d}|\vec{u}| u}{\rho 0} \\
K_{M v} \frac{\partial v}{\partial z}=\frac{-C_{d}|\vec{u}| v}{\rho 0} \\
K_{T v} \frac{\partial T}{\partial z}=0 \\
K_{S v} \frac{\partial S}{\partial z}=0
\end{gathered}
$$

Navier-Stokes equation is used in diagnostic analysis:

$$
\begin{array}{r}
\frac{\partial u}{\partial t}+u \frac{\partial u}{\partial x}+v \frac{\partial u}{\partial y}+w \frac{\partial u}{\partial z}-f v= \\
-\frac{1}{\rho_{0}} \frac{\partial P}{\partial x}+\operatorname{Diff}(u)
\end{array}
$$

The model domain extends between $2^{\circ} \mathrm{S}-8 \mathrm{~S}$ and $116{ }^{\circ} \mathrm{E}$ to $122{ }^{\circ} \mathrm{E}$. The number of model grid is $83 \times 72$ points with a horizontal resolution of $1 / 12^{\circ}$. The model has 32 vertical levels, and the vertical grid is stretched for increased boundary layer resolution. Model simulation has been performed for 10 years simulation. The $10^{\text {th }}$ year simulation was chosen for this study since it is considered to have reached the statistical balance.

\subsection{Description of Experiments}

A set of three experiments was carried out to assess the oceanic response to the topography (Selayar Strait) and its sensitivity to the boundary conditions. The three experiments named Scenario \#1, Scenario \#2 and Scenario \#3. Scenario 1 was the control run experiment. As a first step, a year simulation was performed with the existence of Selayar Strait which separates Southern Sulawesi and Selayar Island.

Scenario 2 was similar to Scenario 1, except that the Selayar Strait was masked with land. This process was done by digitizing the land mask on the gridmaking process. In addition, the slipperiness value in this scenario was +1 . This value shows the condition of free slip. Scenario 3 was also similar to Scenario 2, except the slipperiness value 
in this scenario was -1 . This value showed the condition of no slip.

\subsection{Model Validation}

Annual cycle of SST was obtained by taking the daily SST value of the numerical model. It was well correlated ( $\mathrm{r}$ $>0.9$ ) to the daily mean SST of NOAA AVHRR satellite imagery (Figure 3) and constantly showed large changes (SST minimum) from July to September. The SST time series from NOAA AVHRR was processed by taking the daily SST between 2007 and 2012 to make a daily annual cycle. Subsequently, the climatological mode was applied to the time series. The minimum SST occurred during the SEM period between July and September, which was about a one-month delay of the southeast monsoon winds. However, the warmest (SST maximum) surface waters occurred during the NWM from December to March.

The meridional currents velocity was compared between the model and previous experiments. It was found that the daily averaged model southward maxi- mum velocity reaches $0.8 \mathrm{~m} / \mathrm{s}$ near $150 \mathrm{~m}$ depth (Figure 4), which was in good agreement with previous experiments conducted by Susanto et al. (2012) and Gordon et al. (2008). These studies showed that in the upper $200 \mathrm{~m}$ velocity clearly exhibits a thermocline intensification with a maximum velocity close to $120 \mathrm{~m}$. Thus, the model showed its suitability to adequately reproduce the observed flow and properties.

\section{RESULTS AND DISCUSSION}

\subsection{Annual Cycle of Upper Circulation}

The climatology of the simulated circulation in MAK was analyzed at three different depth levels $(10 \mathrm{~m}, 50 \mathrm{~m}$ and 100 $\mathrm{m}$ ) (not shown) and seasonal periods as shown in Figure 5. Much stronger ITF flow occurred during the SEM (June to August), which generated a strong recirculation in the southern tips of Sulawesi Island. However, during the NWM, strong surface flows came from Java Sea to Banda Sea, and a strong flow during the SEM came from the ITF branch. During

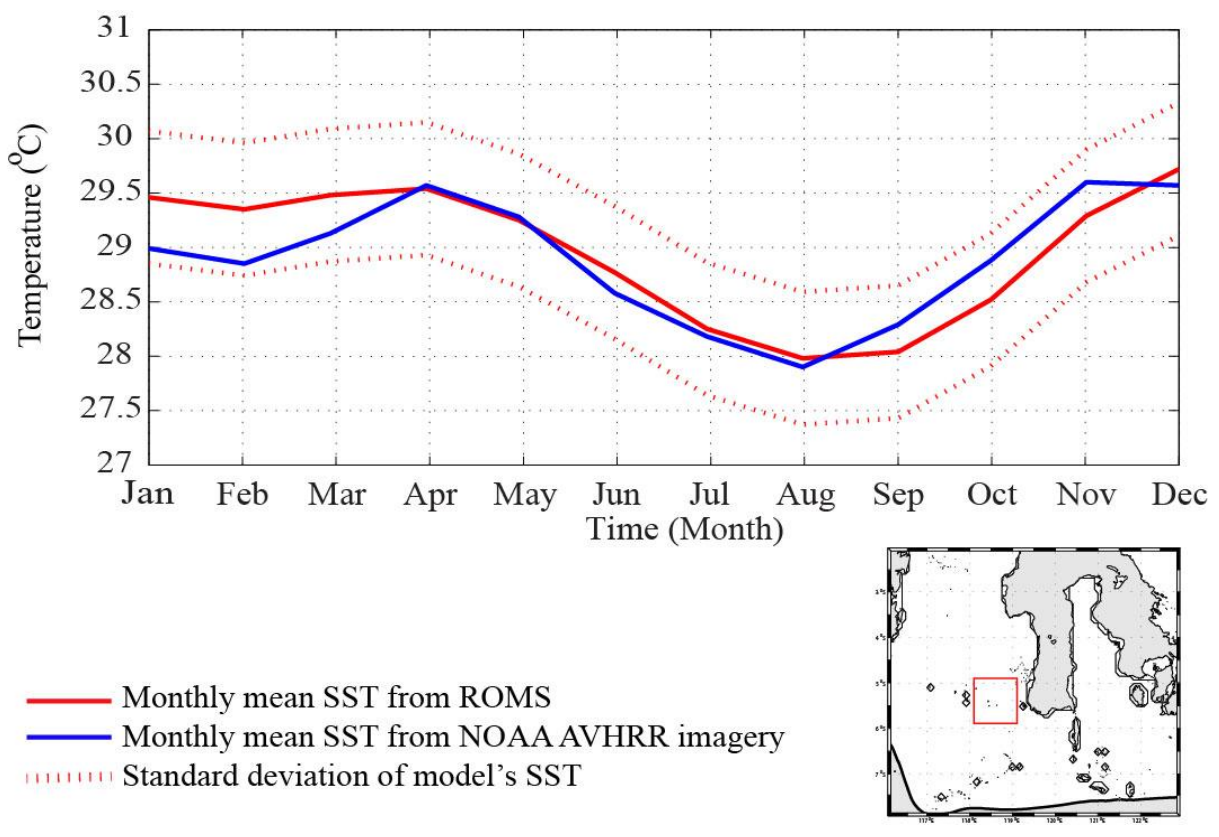

Figure 3. The validation result of ROMS SST and NOAA AVHRR SST satellite imagery. 

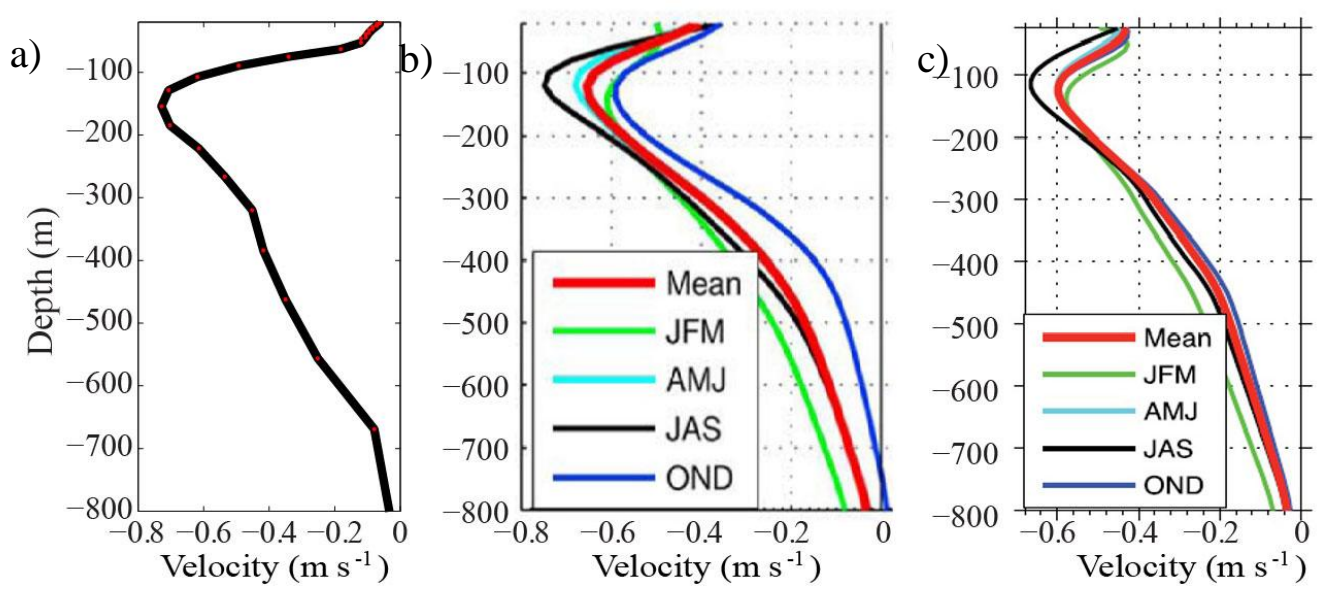

Figure 4. The MAK depth profiles of velocity near Libani channel (a) computed by model for the period of 1 year, (b) derived from the ADCP and current meter data for the period January 2004 through May 2009 (Susanto et al., 2012) and (c) derived from the ADCP and current meter data for the period 2004 to 2006 (Gordon et al., 2008). The vertical coordinates are given in decibar (dbar), which is approximately a meter (m). Figure 4b, 3c shows 3-month averaged velocity profile for January to March (JFM), April to June (AMJ), July to September (JAS), and October to December (OND).

the SEM, the southeasterly wind speeds are fully developed and are parallel to the coastline. The southeasterly winds begin to intensify in June. However, in the second half of June until early July the wind speeds slightly decrease, denoting a relaxation of the monsoon winds (Habibi et al., 2010).

The surface currents at $10 \mathrm{~m}$ and 50 $\mathrm{m}$ (not shown) are partly deflected through Selayar Strait and recirculate to the ITF pathway. The complexity of the topography and coastline at the entrance of the MAK induce an Eddy-type through flow rather than a straightforward flow (Kartadikaria et al., 2012). It is also agree with Kartadikaria et al., (2012), which found the Eddy-type throughflow based on model results and the results of drifters release field experiment around the target western Flores Sea region and examined the influence of eddies on the vertical temperature structure through verification using the available existing dataset. The existence of a steep deep basin (>500 m depth) between the Java and Flores seas indicates a possible area for eddies. The recirculation on the ITF pathway is associated with the Southeast Monsoon that passes the southern Makassar Strait. The development of wind stress curls during Southeast Monsoon generates an anticyclonic eddy pattern in the north of Sumbawa Island (Southern Makassar Strait) (AMJ and JAS on Figure 5). It is in good agreement with Kartadikaria et al. (2012), that the upwelling region found to the east of the Flores Eddy (FE) may represent a key origin of mass transport for the convergence comprising the Ekman induced upwelling in the FE region. In figure 5 this is highlighted by white arrows on JAS period. This process causes an upwelling of deep sea water to the sea surface. This water mass accumulation shapes an anticyclonic eddy pattern that deepens the mixed layer and the thermocline in Flores Sea. 


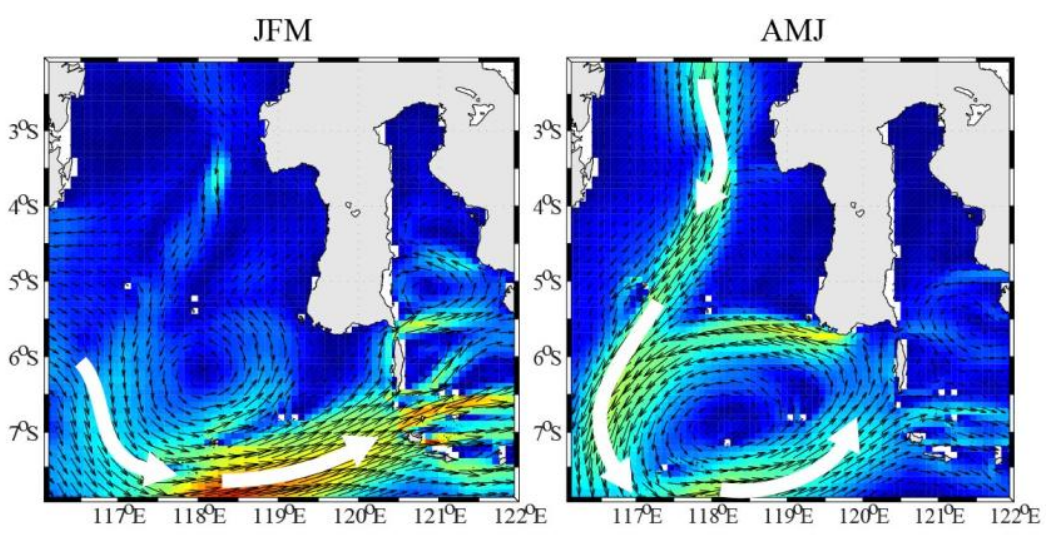

JAS

OND

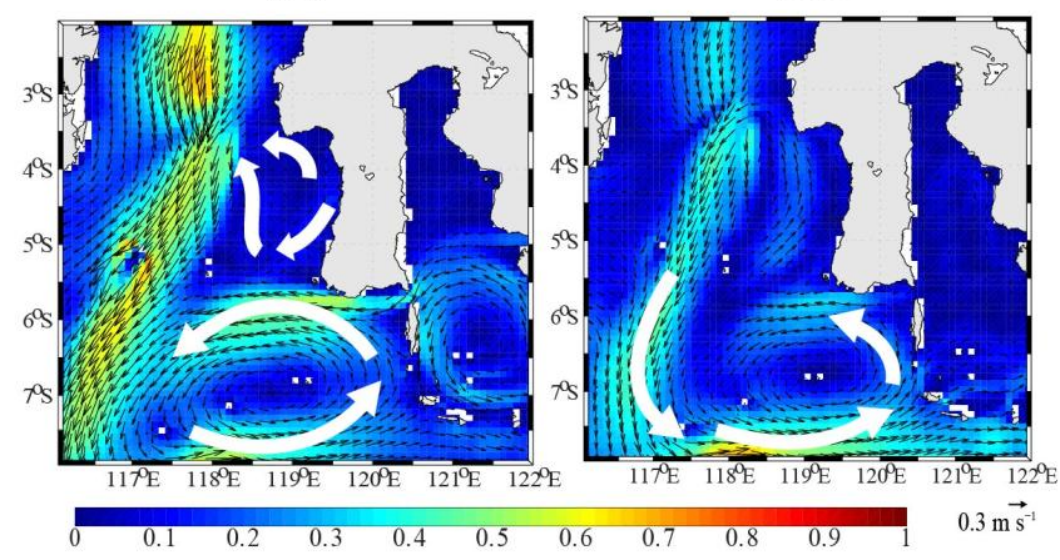

Figure 5. Seasonal variability of sea surface currents. The figure shows 3-month averaged velocity profile for January to March (JFM), April to June (AMJ), July to September (JAS), and October to December (OND).

\subsection{The Interaction of Topography on SST and Sea Currents}

SST modelling was conducted by calculating the average of daily SST data into the monthly SST for one year computation. Three scenarios were applied to describe the main factors which generate the upwelling system of southern Makassar Strait. A control experiment (Figure 6) showed that the upwelling region of southern Makassar Strait has a lower temperature compared to other close-by regions over the entire model period, with high an intensification of the cool surface water during the Southeast Monsoon. The SST reached a minimum on August of less than $25{ }^{\circ} \mathrm{C}$. The SST startd to decrease in May and to increase in September. A previous study showed that a low SST area clearly appears in
June and gradually develops until August. In September, the Southern Makassar Strait begins to warm up in September (Setiawan et al., 2010). From this result, we could conclude that the upwelling event in MAK was indicated by strong surface winds during the SEM, which potentially generate a wind-driven upwelling.

The model results for Scenario 2 (Figure 7) and Scenario 3 (not shown) showed a much larger area of upwelling in the southern Makassar Strait. The presence of Selayar Island in Southern Sulawesi Island played a dominant role as a barrier for the (MAK) flow to the Flores/Banda Seas. This condition caused the west-ward currents to generate a halfrecirculation following the ITF route. The land masses connecting Sulawesi island 

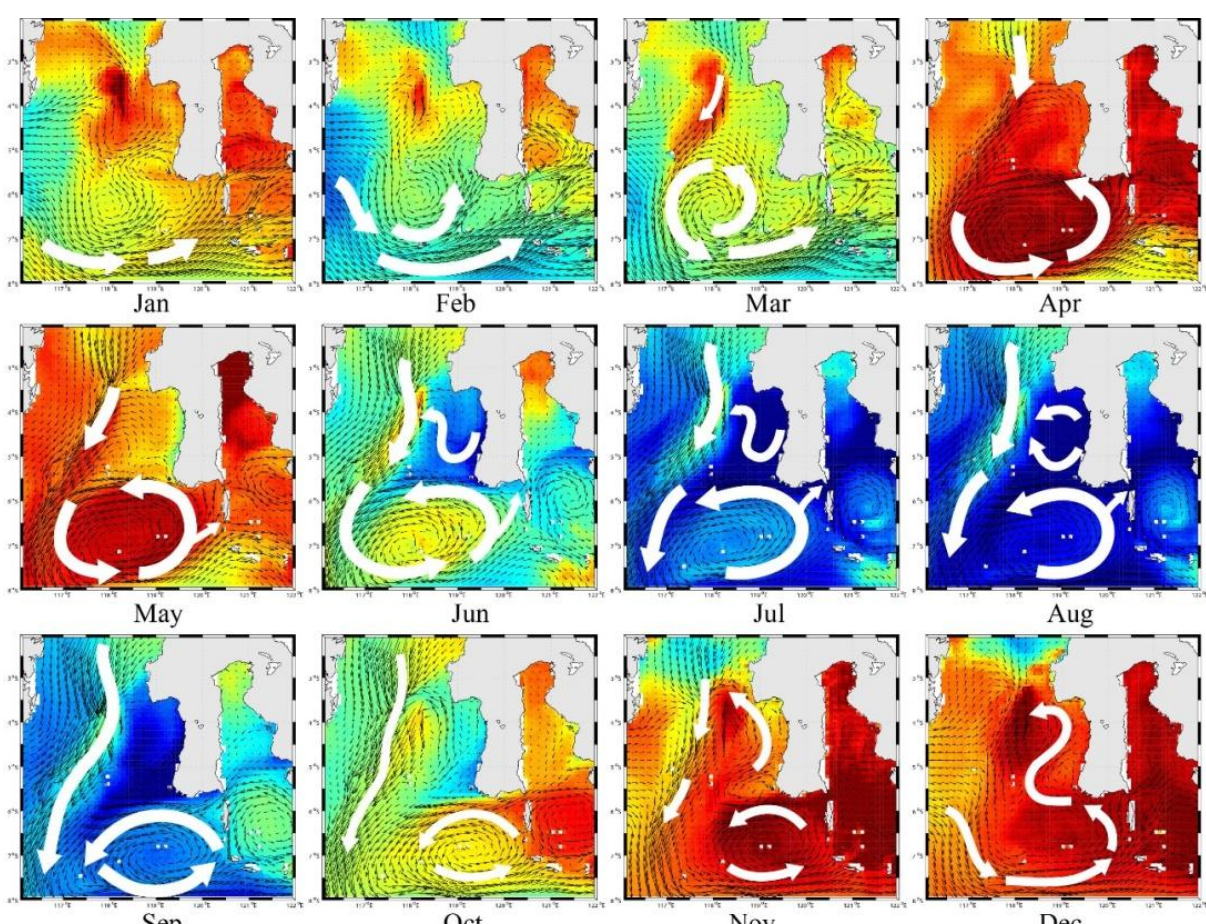

Jul

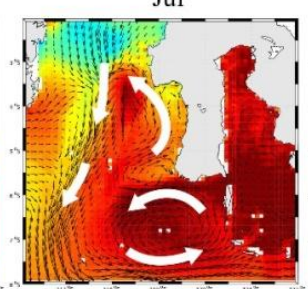

Aug
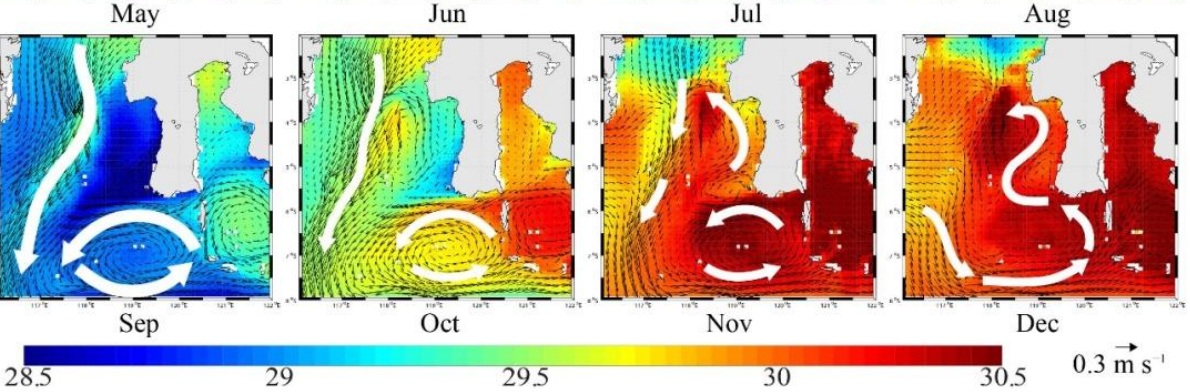

Nov $50.3 \overrightarrow{\mathrm{m} \mathrm{s}}$

Figure 6. Evolution of SST and sea currents for Scenario 1 (control experiment). SST is computed for yearly mean in one year at depth $10 \mathrm{~m}$.
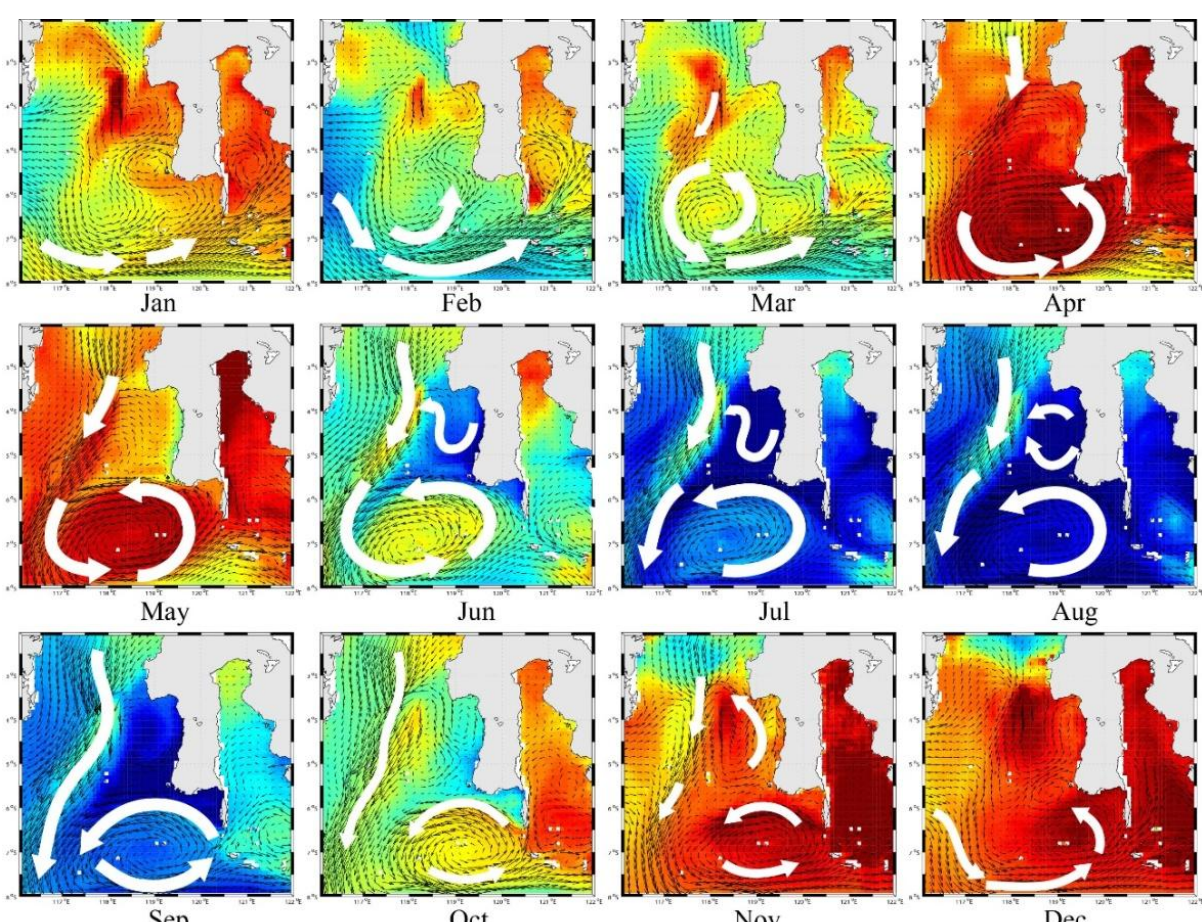

Aug

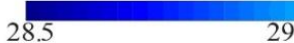

Oct

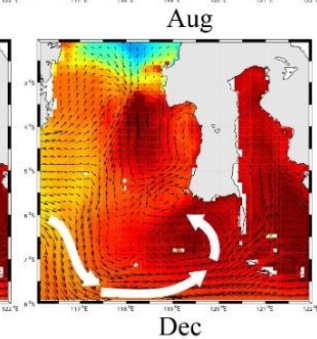

29.5

$0.3 \overrightarrow{\mathrm{m} \mathrm{s}}$

Figure 7. Evolution of SST and sea currents for Scenario 2. SST is computed for yearly mean in one year at depth $10 \mathrm{~m}$. Selayar Strait closure was digitized by defined it into land which connects the Selayar Island with Sulawesi Island. 
and Selayar Island generated an upwelling in the southern Makassar Strait. This was caused by a narrow passage for the eastward currents to directly cross the southern Makassar Strait. This recirculation developed into a convergence area for surface and subsurface currents into the ITF pathway. High transport volumes and velocity of ITF during the SEM, provoked the surface currents to form a strong eddy. Consequently, a coastal divergence occurred around the southern part of the Sulawesi Island's coast and the balance between wind stress and Coriolis lead the Ekman transport directed toward the southwest, away from the coastline.

\subsection{The Relations between Atmosphe- ric and Oceanic Variables on Upwelling Intensity}

Atmospheric variables (Figure 8) showed a distinct variation during the SEM. A drastic change of SST occurred in May with an SST minimum in August. The SST started to increase in October with its peak in April. A similar pattern was found in meridional wind stress with a maximum intensity in August. Low temperatures occurred in the coastal area (highlighted by point $\mathrm{A}$ in Figure 8), and increase at point $\mathrm{B}$. This fluctuation also corroborated with wind stress (zonal and meridional), and shortwave radiation components.

Wind stress played a major role in SST changes during the upwelling period. Strong wind stress was correlated with strong wind speed in southeasterly direction during the SEM. Heat flux components showed that longwave radiation and sensible heat reveal much higher heat loss compared to the other components. Heat transfers between the atmosphere and the sea surface are caused by conduction and convection processes as well as evaporation and surface stress (tension). The increase of heat flux wa influenced by wind stress intensity enhan- cement (Sterl et al., 2003). It was consistent with Renault et al. (2012), that winds intensification could increase the heat loss by heat flux. Temperature decrease by surface heat flux in surface layer was distributed horizontally toward offshore, which may cause an unstable convection condition. Strong mixing by wind caused vertical mixing in water column. This results in a relay process that carries the water mass to the surface through upwelling process.

Oceanic variables in transect A-B (Figure 9) showed similar variations between sea surface temperature, potential temperature, salinity, sea surface elevation and vertical diffusivity during the Southeast Monsoon (June-October). An increase of vertical diffusivity was followed by low temperatures. This condition was caused by strong intensity of winds during the Southeast Monsoon which caused a water transport of high salinity water from Makassar Strait ti Flores Sea and Banda Sea (Gordon et al., 2003).

Vertical sections of oceanic variables (Figure 10) were computed for February and August. These months represented the period of NWM and SEM seasons. Low SST and high salinity in (MAK) indicated an upwelling event that occurred during the SEM. It followed the fluctuation pattern of zonal and meridional velocity and kinetic energy. During this season, zonal and meridional velocities increase and the currents flow southwestward, away from the coastal area. Intensification of kinetic energy and velocity within the sea surface contributes to strong mesoscale activities (jets and eddies), which were typical to the characteristics of upwelling (Lathuiliére et al., 2010).

\subsection{Diagnostic Analysis}

Diagnostic analysis was computed to analyze the contribution of each of the surface forcing components. The vertical 


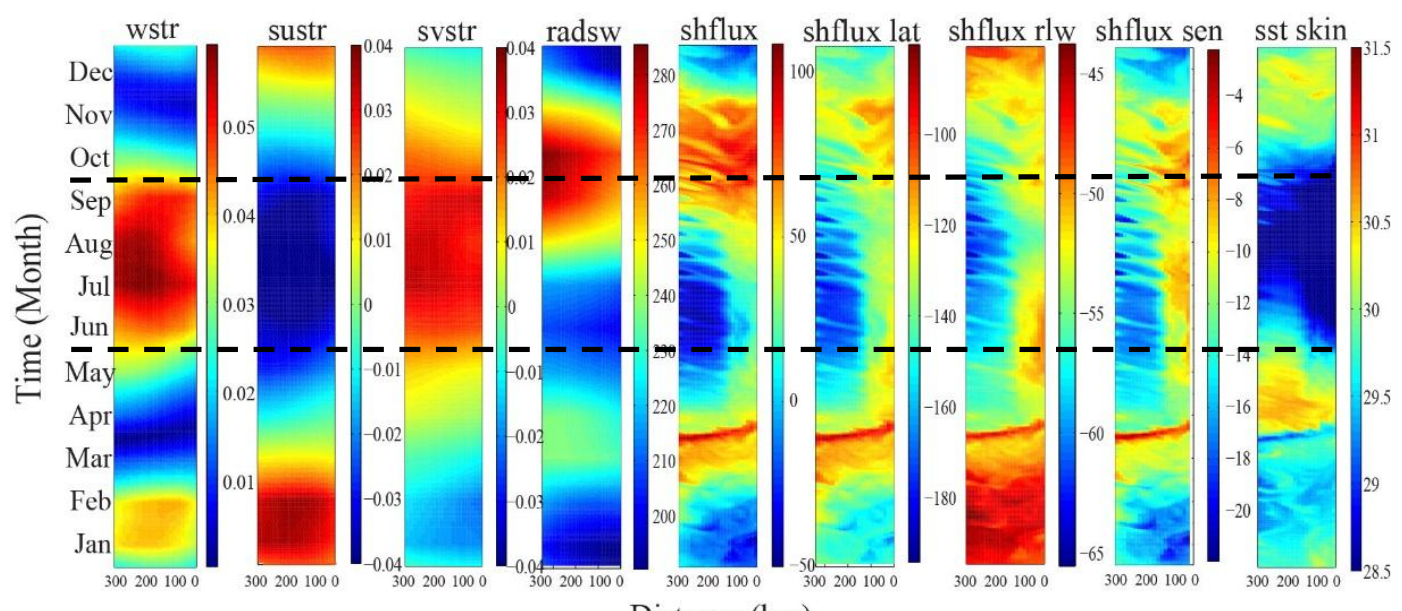

$$
\begin{array}{ll}
\text { Sst skin } & =\text { sea surface temperature }\left({ }^{\circ} \mathrm{C}\right) \\
\text { wstr } & =\text { wind stress }\left(\mathrm{N} \mathrm{m}^{-2}\right) \\
\text { sustr } & =\text { zonal wind stress }\left(\mathrm{N} \mathrm{m}^{-2}\right) \\
\text { Svstr } & =\text { meridional wind stress }\left(\mathrm{N} \mathrm{m}^{-2}\right) \\
\text { radsw } & =\text { shortwave surface radiation }\left(\mathrm{W} \mathrm{m}^{-2}\right) \\
\text { shflux } & =\text { surface net heat flux }\left(\mathrm{W} \mathrm{m}^{-2}\right) \\
\text { shflux lat } & =\text { net latent heat flux }\left(\mathrm{W} \mathrm{m}^{-2}\right) \\
\text { shflux rlw } & =\text { longwave radiation }\left(\mathrm{W} \mathrm{m}^{-2}\right) \\
\text { shflux sen } & =\text { net sensible heat flux }\left(\mathrm{W} \mathrm{m}^{-2}\right)
\end{array}
$$

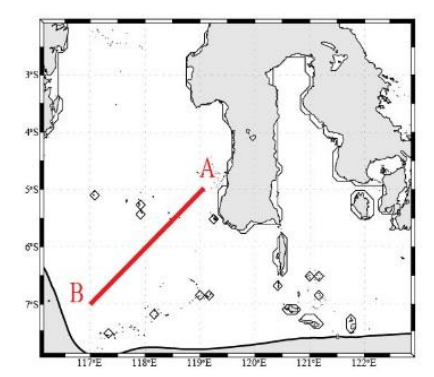

Figure 8. Hovmüller diagram of atmospheric variables over the transect A-B.

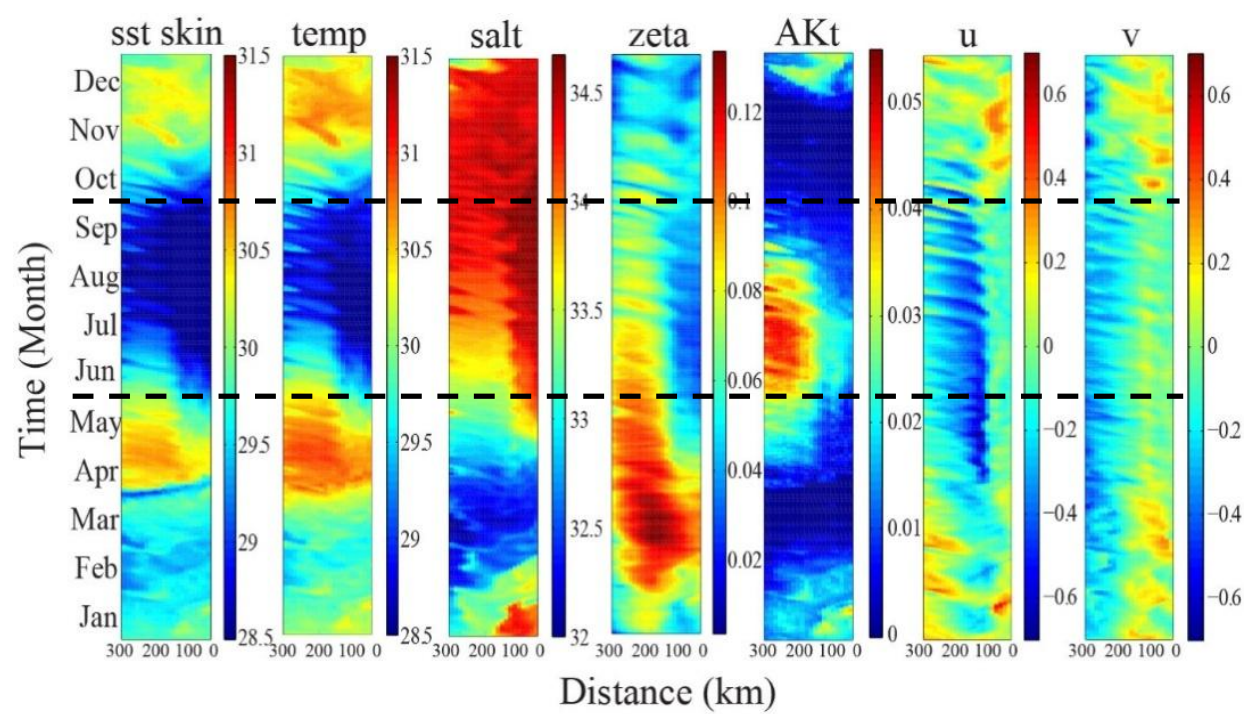

$$
\begin{array}{ll}
\text { sst skin } & =\text { sea surface temperature }\left({ }^{\circ} \mathrm{C}\right) \\
\text { temp } & =\text { potential temperature }\left({ }^{\circ} \mathrm{C}\right) \\
\text { salt } & =\text { salinity }(\mathrm{psu}) \\
\text { zeta } & =\text { surface elevation }(\mathrm{m}) \\
\text { AKt } & =\text { vertical diffusivity for temperature }\left(\mathrm{m}^{2} \mathrm{~s}^{-1}\right) \\
\mathrm{u} & =\text { zonal momentum component }\left(\mathrm{m} \mathrm{s}^{-1}\right) \\
\mathrm{v} & =\text { meridional momentum component }\left(\mathrm{m} \mathrm{s}^{-1}\right)
\end{array}
$$

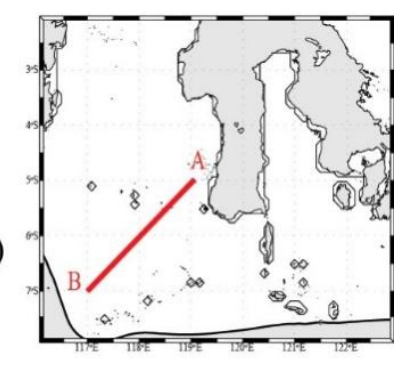

Figure 9. Hovmüller diagram of oceanic variables in transect A-B. 
A Numerical Modeling Study on Upwelling ...

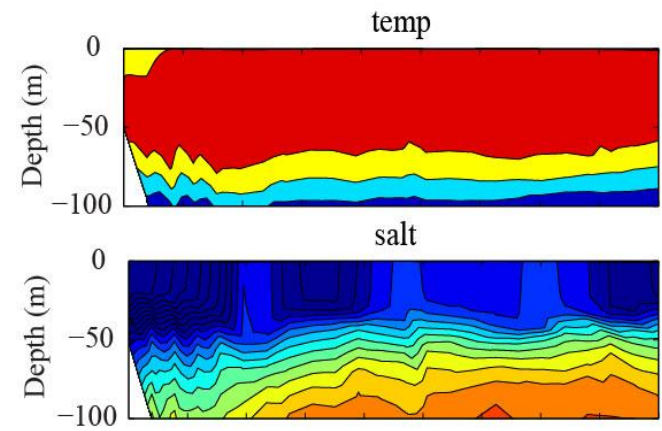

$\mathrm{u}$
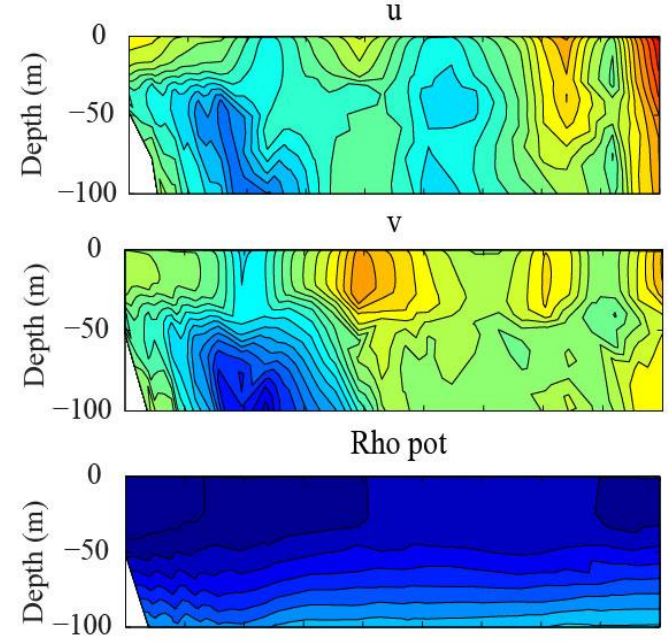

$\mathrm{Ke}$

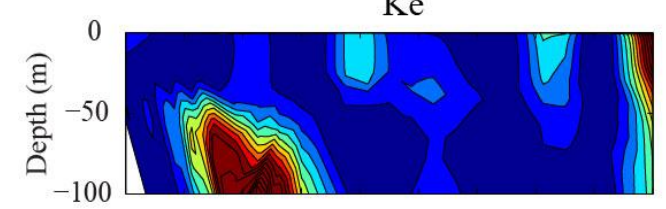

Speed

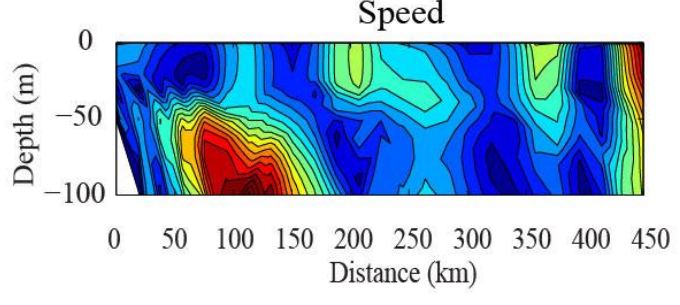

temp $=$ potential temperature $\left({ }^{\circ} \mathrm{C}\right)$

salt = salinity (psu)

$\mathrm{u} \quad=$ zonal momentum component $\left(\mathrm{m} \mathrm{s}^{-1}\right)$

$\mathrm{v}=$ meridional momentum component $\left(\mathrm{m} \mathrm{s}^{-1}\right)$

$\mathrm{Ke}=$ horizontal slice of kinetic energy

Rhopot $=$ horizontal slice of the potential density

Speed = horizontal slice of the ocean currents velocity
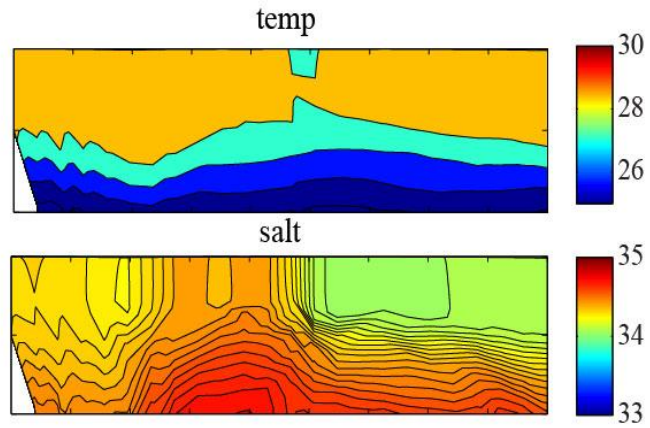

$\mathrm{u}$

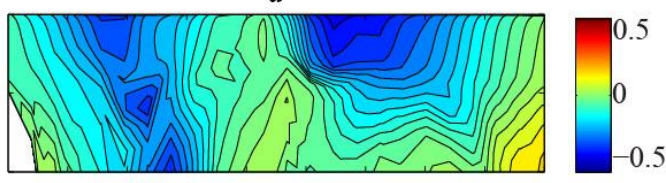

$\mathrm{V}$
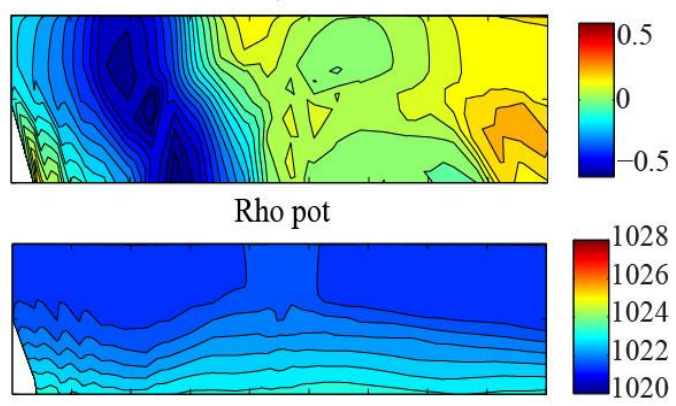

$\mathrm{Ke}$

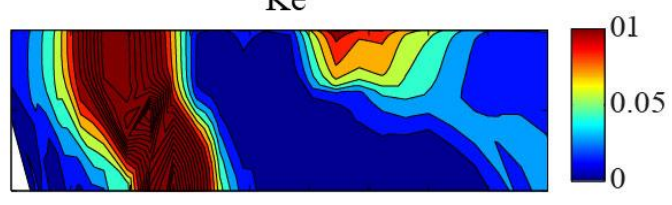

Speed

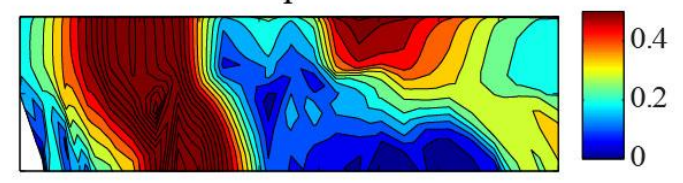

$\begin{array}{llllllllll}0 & 50 & 100 & 150 & 200 & 250 & 300 & 350 & 400 & 450\end{array}$ Distance $(\mathrm{km})$

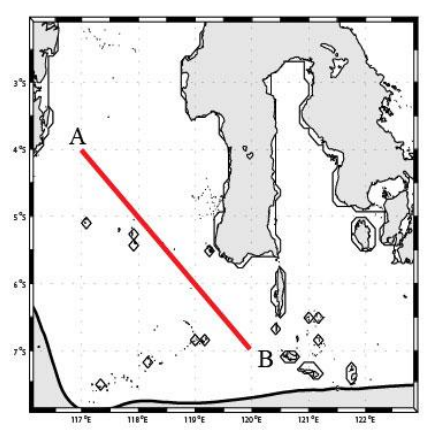

Figure 10. Vertical section of oceanic variables for February (Northwest Monsoon) (left) and August (Southeast Monsoon) (right). 
advection has a higher value during the Southeast Monsoon (Figure 11), contrast to the horizontal advection. Advection is a process of water properties transport (heat, salinity, other properties) through sea wave (Kämpf, 2009). The meridional component shows the southward flow in the ITF path. It is caused by a high intensity of ITF's transport in southern Makassar Strait. This condition results in a heat change and a deeper mixed layer depth, raised by southeast monsoon winds over the southern Makassar Strait. Similar to the advection, pressure gradients and vertical mixing components were much higher during the SEM. A high pressure gradient indicated a high density gradient in southern Makassar Strait. This condition triggerred the upwelling event in this area.

Vertical mixing processes caused vertical diffusion and vertical advection.

Wind stress generated horizontal advection and vertical mixing. These mechanisms changed the water density. Horizontal advection provided the most signi-
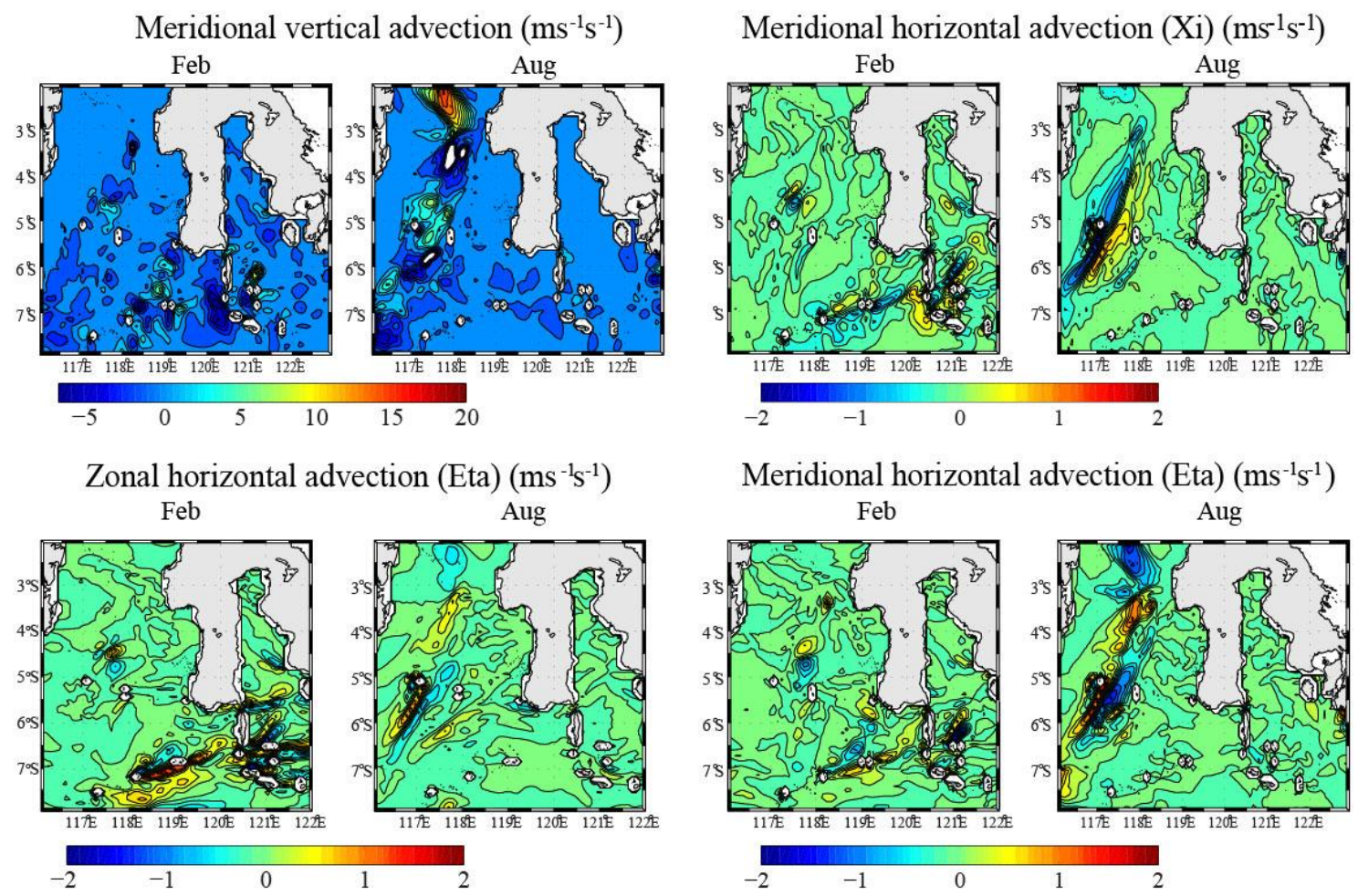

Meridional horizontal advection (Eta) $\left(\mathrm{ms}^{-1} \mathrm{~s}^{-1}\right)$

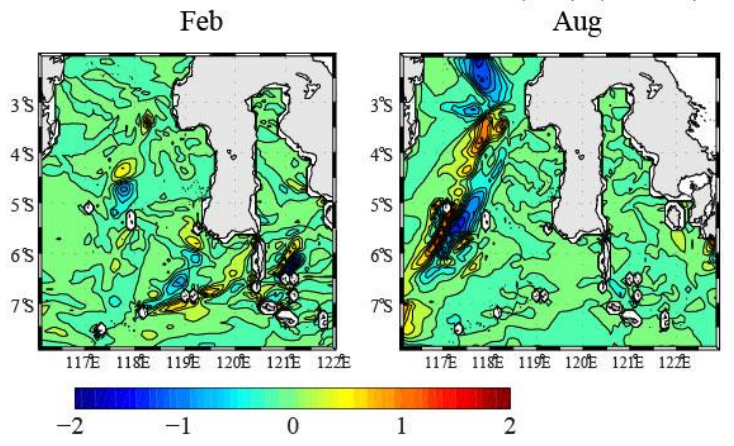

Meridional Vertical Mixing $\left(\mathrm{ms}^{-1} \mathrm{~s}^{-1}\right)$

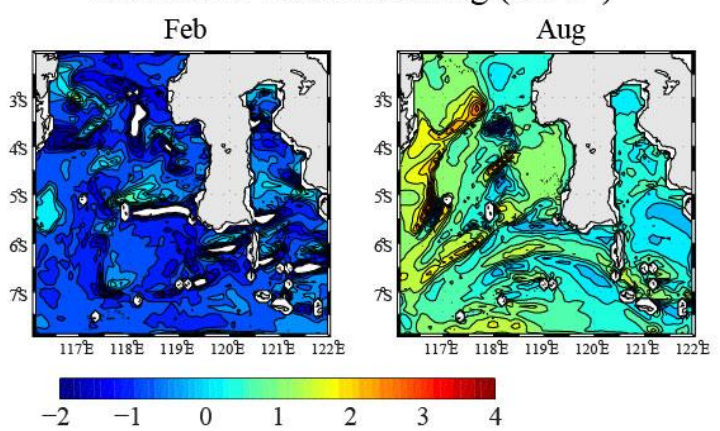

Meridional Pressure Gradient $\left(\mathrm{ms}^{-1} \mathrm{~s}^{-1}\right)$

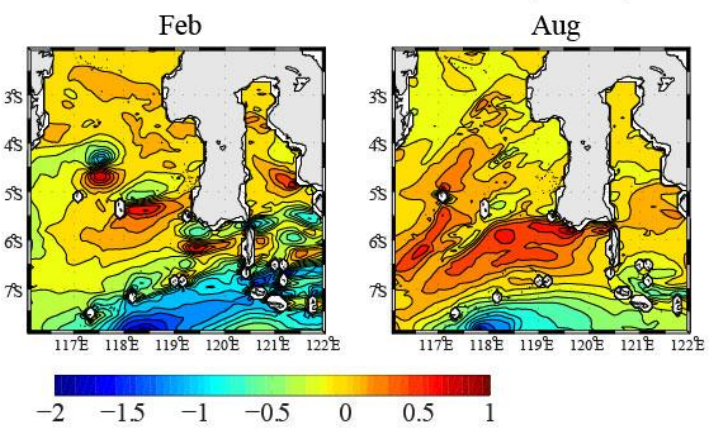

Figure 11. Components of forcing for February (Northwest Monsoon) and August (Southeast Monsoon) in Southern Makassar. 
ficant effect with a strong variability (Foltz et al., 2006). High pressure during the SEM caused the currents flow towards water with lower pressure, which results in horizontal and vertical gradient of density. The Coriolis effect plus the frictional coupling of wind and water (Ekman transport) directed the surface currents in a $90^{\circ}$ angle to the left from the coastal area with a constant pressure and conducts a coastal divergence.

\subsection{Proposed Mechanism of Upwelling}

In Figure 12 the proposed mechanism and physical processes of the upwelling, as performed by the model, were summarized. The mechanism of upwelling in MAK was mainly generated by the Southeast Monsoon winds blowing over this area from June to August (Figure 12), inducing a wind-driven upwelling associated with Ekman pumping. High Ekman pumping occurred in the MAK from July to September with strong affection of wind stress and caused a decrease of the SST and an increase in primary production in this area (Gordon et al., 2005).

Wind stress blew strongly to the northwest during this season and caused an increase of vertical diffusivity. Moreover, it resulted in a positive heat flux (heat loss). The heat floss due to heat flux lead to an increase of water density and vertical mixing, which also was influenced by the combination of vertical diffusivity and vertical velocity. This condition caused upwelling in MAK.

Moreover, the SEM winds also caused a change in the advection (horizontal and vertical), the pressure gradient and the vertical mixing, which in turn, affected the water density.

Both the ITF recirculation and the presence of the Selayar Strait had a role to provoke the upwelling occurrence in

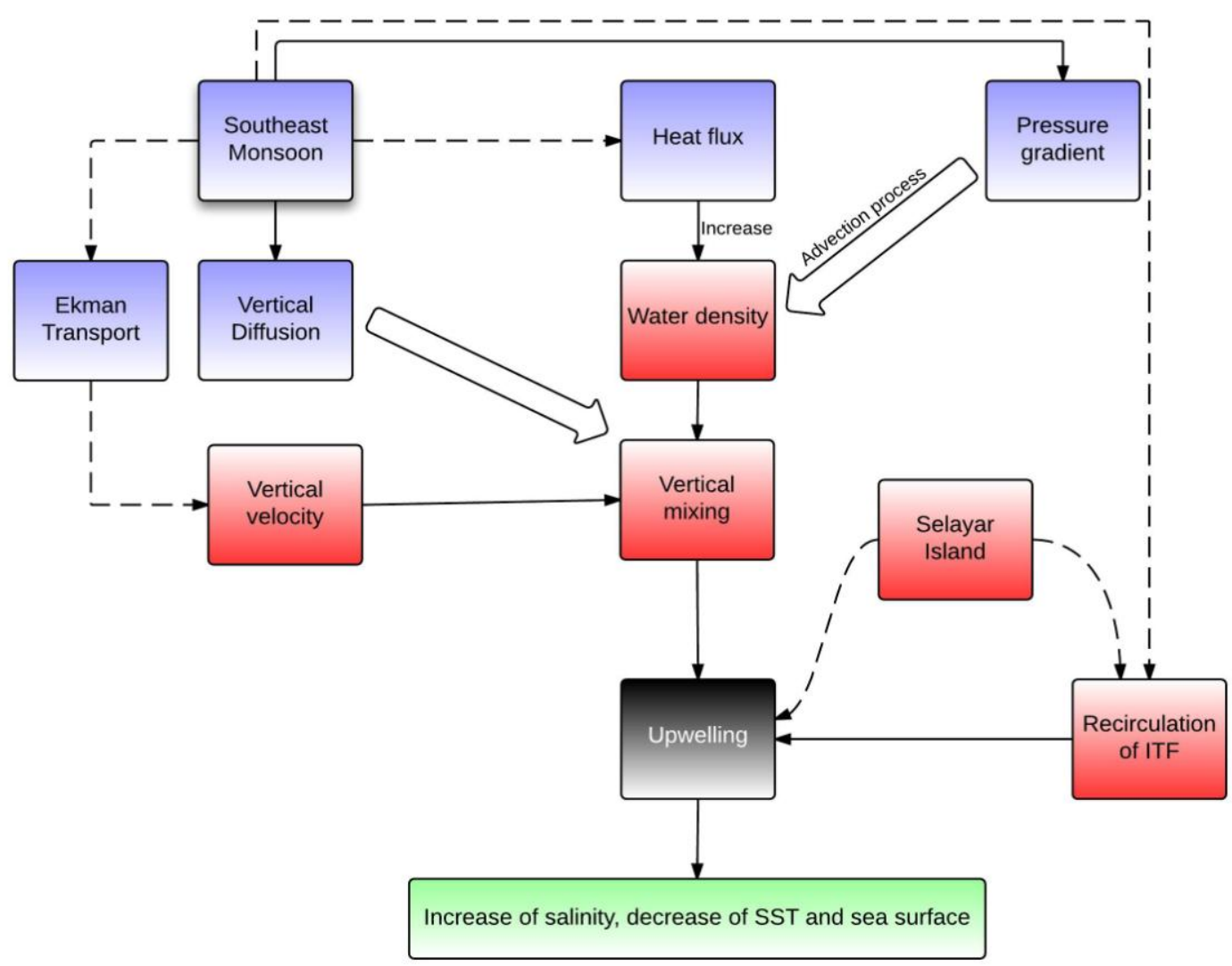

Figure 12. Proposed mechanism of upwelling in MAK. 
MAK. The presence of Selayar Strait as a barrier for the current outflow to Flores Sea and the complex topography in this area caused the sea current to return to ITF pathway and to form an Eddy, which was associated with the Southeast Monsoon. This condition set an increase of upwelling intensity and results in a decrease of temperature and surface elevation as well as an increase of salinity.

\section{CONCLUSIONS}

The cause of upwelling in southern Makassar Strait, indicated by the decrease of temperature during the SEM was the background for the hypotheses of the mechanism of upwelling in this area. The model revealed that the mechanism of upwelling was mainly associated with Southeast Monsoon winds, which fully developed over MAK between June and August. During this season, strong winds triggered the vertical diffusivity. High intensity of wind stress also enhanced the heat loss by heat flux. This condition resulted in a strong vertical mixing.

ITF in Makassar Strait played a role in affecting the mechanism of upwelling. ITF caused a recirculation by forming an eddy that caused a convergence in the pathway of the ITF and a divergence in the coastal area. The Selayar Strait in southern of Sulawesi Island was the gate for the outflow current from this recirculation and the current was partially deflected to Flores Sea. It showed that Selayar Strait had a minor role in decreasing the intensity of upwelling and the existence of Selayar Island and complexity of topography triggered the ITF recirculation. From these results we concluded that the upwelling mechanism was caused by the combination of the three hypotheses which were mainly associated with Southeast Monsoon winds.
The Southeast monsoon winds could be the main factor for the upwelling mechanism in the Southern Makassar Strait. For this reason, further research in this study is highly needed by setting up real calendar years in computation. Furthermore, a diagnostic analyses in the bottom boundary layer and mixed layer depths are needed to understand the contribution of each forcing component to the upwelling processes. A model experiment by setting different winds directions, e.g., southerly or northerly winds and flattering bathymetry of MAK are also needed to investigate the role of topography in the eddy formation.

\section{ACKNOWLEDGEMENTS}

The authors are grateful to the ROMS developers, particularly to Dr. Gildas Cambon and Prof. Patrick Marchesiello for their support, discussion, and comments on this work. We also wish to thank to the reviewers for their advice on how to improvement early version of this manuscript.

\section{REFERENCES}

Atmadipoera, A., R. Molcard, G. Madec, S. Wijfels, J. Sprintall, A. KochLarrouy, I. Jaya, and A. Supangat. 2009. Characteristics and variability of the Indonesian Throughflow Water at the outflow Straits. Deep Sea Research I, 56:1942-1954.

England, M. and F. Huang. 2005. On the interannual variability of the Indonesian Throughflow and its linkage with ENSO. J. Clim., 18:14351444. doi:10.1175/JCLI3322.1.

Foltz, G.R. and McPhaden, M.J. 2006. The role of oceanic heat advection in the evolution of tropical North and South Atlantic SST anomalies. J. Clim., 19:6122-6138. 
Gordon, A.L., R.D. Susanto, and K. Vranes. 2003. Cool Indonesian throughflow as a consequence of restricted surface layer flow. Nature, 425: 824-828.

Gordon, A.L. 2005. Oceanography of the Indonesian Seas and their throughflow. Oceanography, 18(4):14-27.

Gordon, A.L., R.D. Susanto, A. Field, B.A. Huber, W. Pranowo, and S. Wirasantosa. 2008. Makassar Strait throughflow, 2004 to 2006. Geo. Res. Let., 35:L24605. doi:10. 1029/2008GL036372.

Gruber, N., Z. Lachkar, H. Frenzel, P. Marchesiello, M. Munnich, J.C. McWilliams, T. Nagai, and G.K. Plattner. 2011. Mesoscale eddyinduced reduction in Eastern boundary upwelling systems. Nat. Geo., 4:787-792.

Gruber, N., H. Frenzel, S.C. Doney, P. Marchesiello, J.C. McWilliams, J.R. Moisan, J. Oram, G.K. Plattner, and K.D. Stolzenbach. 2006. Simulation of phytoplankton ecosystem dynamics in the California Current System. Deep-Sea Res. PTI., 53:1483-1516.

Habibi, A., R.Y. Setiawan, and A.Y. Zuhdy. 2010. Wind-driven coastal upwelling along South of Sulawesi Island. Ilmu Kelautan, 15(2):115118.

Kämpf, J. 2009. Ocean modelling for beginners. Springer: London. $175 \mathrm{p}$.

Karakas, G., N. Nowald, M. Blaas, P. Marchesiello, S. Frickenhaus, and R. Schlitzer. 2006. High-resolution modeling of sediment erosion and particle transport across the Northwest African shelf. J. Geophys. Res., 111:C06025. doi:10.1029/20 05JC003296.

Kartadikaria, A.R., Y . Miyazawa, K. Nadaoka, and A. Watanabe. 2012. Existence of eddies at crossroad of the Indonesian seas. Oce. Dyn., 62:31-44. doi:10.1007/s102360110489-1.

Lathuiliére, C., V. Echevin, M. Lévy, and G. Madec. 2010. On the role of the mesoscale circulation on an idealized coastal upwelling ecosystem. J. Geophys. Res., 115:C09018. doi:10.1029/2009JC005827.

Marchesiello, P. and P. Estrade. 2010. Upwelling limitation by geostrophic onshore flow. J. Mar. Res., 68:37-62.

Marta-Almeida, M., M. Ruiz-Villarreal, P. Otero, M. Cobas, A. Peliz, R. Nolasco, M. Cirano, and J. Pereira. 2010. OOF $_{\varepsilon}$ : a python engine for automating regional and coastal ocean forecasts. Environ. Modell Softw., 26:680-682. doi:10.1016/ j.envsoft.2010.11.015.

Messie, M., M. Radenac, J. Lefevre, and P. Marchesiello. 2006. Chlorophyll bloom in the Western Pacific at the end of the 1997-98 El Nino: the role of Kiribati Islands. Geo. Res. Let., 33(14):L14601. doi:10.1029/ 2006GL026 033.

Penven, P., P. Marchesiello, L. Debreu, and J. Lefevre. 2007. Software tools for pre- and post-processing of oceanic regional simulations. Environ. Modell Softw., 20:1-3. doi:10.1016/j.envsoft.2007.07.004

Renault, L., B. Dewite, P. Marchesiello, S. Illig, V. Echevin, G. Cambon, M. Ramos, O. Astudillo, P. Minnis, and J.K. Ayers. 2012. Upwelling response to atmospheric coastal jets off central Chile: a modeling study of the October 2000 event. $J$. Geophys. Res., 117:C02030. doi: 10.1029/2011JC007446.

Setiawan, R.Y. and H. Kawamura. 2010. Summertime phytoplankton bloom in the South Sulawesi Sea. IEEE J. Sel. Topics Appl. Earth Observ., 
1939-1404pp. doi:10.1109/JSTAR S.2010.20946.

Sterl, A. and W. Hazeleger. 2003. Coupled variability and air-sea interaction in the South Atlantic Ocean. Clim. Dyn., 21:550-571.

Susanto, R.D., A. Ffield, A.L. Gordon, and T.R. Adi. 2012. Variability of Indonesian throughflow within Makassar Strait, 2004-2009. J. Geophys. Res., 117:C09013. doi:10.1029/2012JC008096.
Syahdan M, S.B. Susilo, J.L. Gaol, dan A.S. Atmadipoera. 2014a (in press). Karakteristik dan variabilitas suhu permukaan laut di Selat Makassar - Laut Jawa. Jurnal Segara.

Syahdan, M., A.S. Atmadipoera, S.B. Susilo, and J.L. Gaol. 2014b. Variability of surface chloropyll-a in Makassar Strait - Java Sea, Indonesia. IJSBAR, 14(2):103-116.

$\begin{array}{ll}\text { Diterima } & : 18 \text { Oktober } 2014 \\ \text { Direview } & : 19 \text { Nopember } 2014 \\ \text { Disetujui } & : 16 \text { Desember } 2014\end{array}$


